\title{
The National Studies Craze
}

The Phenomena, the Controversies, and Some Reflections

\section{Chen Jiaming}

Translator. Stacy Mosher

\section{OpenEdition}

\section{Journals}

\section{Electronic version}

URL: http://journals.openedition.org/chinaperspectives/5373

DOI: 10.4000/chinaperspectives.5373

ISSN: 1996-4617

\section{Publisher}

Centre d'étude français sur la Chine contemporaine

\section{Printed version}

Date of publication: 1 January 2011

Number of pages: $22-30$

ISSN: 2070-3449

\section{Electronic reference}

Chen Jiaming, «The National Studies Craze », China Perspectives [Online], 2011/1 | 2011, Online since

30 March 2014, connection on 28 October 2019. URL : http://journals.openedition.org/

chinaperspectives/5373; DOI : 10.4000/chinaperspectives.5373 


\title{
The National Studies Craze
}

\author{
The Phenomena, the Controversies, and Some Reflections
}

\author{
CHEN IIAMING*
}

\begin{abstract}
This article first gives a brief description of the phenomena of the revival of traditional studies and culture (Guoxue Craze) in mainland China, then presents and critiques the controversies that surround them, including questions of what "national studies" are, whether the national studies craze is "artificial heat," and the emergence of "Confucian fundamentalism" in the national studies craze, etc. It finally offers some reflections on these phenomena, such as the danger of getting bogged down in parochial nationalism; the infeasibility of China relying on Confucian traditional culture to achieve modernisation; and the absurdity of attempts by Confucian fundamentalism to use "Confucianism to solve all of China's problems."
\end{abstract}

KEY WORDS: national studies craze, China's modernisation, Confucian fundamentalism

$\mathrm{B}$ eginning in the 1980s, a new trend emerged in mainland China for the revival of traditional studies and culture, in particular a revival of Confucianism, giving rise to related activity such as the establishment of "national studies institutes" at universities and teaching children to read the classics. This intellectual trend and related activities are referred to as the "national studies craze." This article will use a brief description of the phenomena as a foundation for presenting and critiquing the controversies that surround them, and offering some of my own reflections, namely, using the angle of "universality" to view the national studies craze and analytically assess its rationality.

\section{The phenomena of the "national studies craze"}

How to treat "national studies," i.e., the issue of China's traditional culture, has constituted a focus of long-term and intense controversy in China's modern and contemporary times, a debate that has risen and fallen in line with China's political and economic terrain. Since the May Fourth Movement, it could be said that progressive and innovative intellectuals, especially the leading thinkers in the New Culture Movement such as Chen Duxiu (陳獨秀), Hu Shi (胡適), and Lu Xun (魯迅), maintained a critical attitude toward traditional thought and culture: "Down with official Confucianism!" was the slogan that emblemised this intellectual trend. By the time Mao Zedong (毛澤東) launched and led the Cultural Revolution, traditional Confucian thought was being labelled as feudalistic, conservative thought, an impediment that Mao had to demolish in order to push forward his own revolutionary thought and line, and it was subjected to organised, widespread criticism throughout the country.

With the end of the Cultural Revolution, the new national policy of reform and opening implemented by China from the end of 1979 onward, achieved impressive economic development, and national strength and its attendant national status were rapidly enhanced. In lockstep with this process, the cultural and social psychology of the Chinese public and government also underwent change. The road to China's modernisation was originally to succeed through "thought liberation movements," including the method of criticising traditional feudal thought, systems, and behaviour to clear away mental impediments, and through learning from the modernisation experience of foreign developed countries (such as market economy, etc.), and integrating it with China's realities in practical application. For this reason, the conflict between the traditional and the modern became especially pronounced during China's modernisation process. China was not like Western countries, which built on an existing foundation rooted in Christianity and ancient Greek culture to rejuvenate the values of their own intellectual circles through a process of Renaissance, Reformation, and Enlightenment, and thereby provided the intellectual and cultural conditions required for their shift toward modern society. Rather, China's modernisation movement was pushed from behind and outside (incited and urged on by external factors). Whether it was the Soviet model adopted during the Mao era, or the Western market economy model from which the Deng Xiaoping (鄧小平) era drew its lessons, China's modernisation process has always been launched and carried out under a series of ideological theories and social practices furnished by the outside world, rather than resulting from the selfrenewal of its own culture. For this reason, one of the resulting conflicts is that in this process of modernisation, China's traditional culture has been marginalised or even regarded as an obstacle that must be surmounted. Under these circumstances, a certain degree of antagonism and divergence has formed between traditional culture and modernisation, and between national character and modernity. In terms of the national psyche, this state of affairs is inevitably hard to accept, and particularly for people with nationalist sentiments, it increases the likelihood of antagonism toward Western culture and toward modernisation in general. This constitutes a background and cause for conflict in the "national studies craze."

It was noted above that the push of the modernisation process brings an increase in national strength and changes to the cultural and social psychology of the people and the government. One fundamental aspect of this change is for an enhanced national self-confidence to be accompanied

\footnotetext{
Chen Jiaming, Professor of the department of philosophy, Xiamen University, China, received his Ph.D. from the Chinese Academy of Social Sciences (1989). He was a Fulbright scholar (2001-2002) at Harvard University and a K. C. Wong Fellow of the British Academy (1995-1996) at St. Andrews University. He has also been a visiting scholar of Marburg University, Germany (1993), and at Amsterdam University, the Netherlands (1999). He is currently chief editor of the Academic Journal of Xiamen University, as well as editor of Philosophical Analysis and of German Philosophy.
} 
by a heightened reassessment of traditional culture. Motivations and knowledge vary greatly, however, between ordinary citizens and officials and between people of different classes. What the government needs is the people's identification with their ethnic identity, their country, and their government; it needs the enhancement of the country's cultural "soft power" in international competition. In terms of the people, individuals with intense national sentiment are unhappy with the pervasive fashion for Western discourse, and hope for a "revitalisation of national studies" as a means of resisting West-centrism; scholars engaged in traditional Chinese studies hope to enhance the status of national studies for professional reasons; and members of the general public derive a cultural pleasure from listening to well-versed lectures on the Confucian Analects or on classic tales like the Legend of the Three Kingdoms. The revival of national studies has thus become the locus for a variety of different emotions and interests. The gradual accumulation of these factors has led to the emergence of the current "national studies craze."

The national studies craze has built up gradually over time. Let us here list some emblematic incidents. In terms of official action, in September 1984, the CCP Central Committee secretariat resolved to establish a government-funded "China Confucian Foundation," with then-State Council member $\mathrm{Gu} \mathrm{Mu}$ (穀牧) serving as honorary president and Kuang Yaming (匡亞明) (1) as president. This marked a major shift in the attitude of China's ruling Party and government toward Confucius. In October 1994, the International Confucius Federation was established, with Gu Mu serving as president, and with the stated aim of "carrying on the cream of Confucianism and developing the spirit of Confucianism." At the same time, the government was organising or supporting various ceremonies honouring Confucius in the sage's native Qufu (曲阜) and other localities. In September 2005, CCTV enhanced the atmosphere by carrying live broadcasts of Confucius ceremonies at temples in Qufu and Shanghai, and in other localities such as Quzhou (倠州), Zhejiang Province; Jianshui (建水), Yunnan Province; and Wuwei (武威), Gansu Province.

In terms of popular action, in November 1986, "Modern Neo-Confucian Studies" was established as a key topic for discussion in the seventh five-year plan of the National Social Sciences Foundation of China, and at the beginning of 1992 it was also listed among the key topics in the eighth five-year plan. This resulted in the works of some Hong Kong and Taiwan Neo-Confucianists being recommended and published on the mainland - for example, the 14-volume series Essentials of Contemporary Neo-Confucianism, edited by Fang Keli, (2) which included representative works by notables Xiong Shili (熊十力), Liang Shuming (梁漱溟), Ma Yifu (馬一浮), Carsun Chang (張君勱), Thome H. Fang (方東美), Feng Yu-Lan (馮友蘭), He Lin (賀麟), Tang Junyi (唐君媇), Mou Zongshan (牟宗三), Xu Fuguan (徐複觀), Tu Weiming (杜維明), Shu-hsien Liu (劉述先), Yu Ying-shih (余英時), and Zhongying Cheng (成中英).

The national studies craze has continued to heat up in the twenty-first century. The year 2004, in particular, saw several incidents relating to Confucianism, including publication of Classics of Chinese Culture for Recitation in Elementary Schools, the convening of the "National Conference for Exchanging Experience on Children's Classical Recitation," and a grandiose "2004 Cultural Pinnacle Forum" held at the Great Hall of the People, during the closing ceremony of which was announced a "Cultural Manifesto of the 甲申, Jiashen Year [2004]" initiated by some famous scholars and signed by 70 participants. That same year saw a symposium marking the 10th anniversary of the publication Yuandao (原道), (3) referred to as "a banner of Chinese cultural conservatism." The symposium discussed views

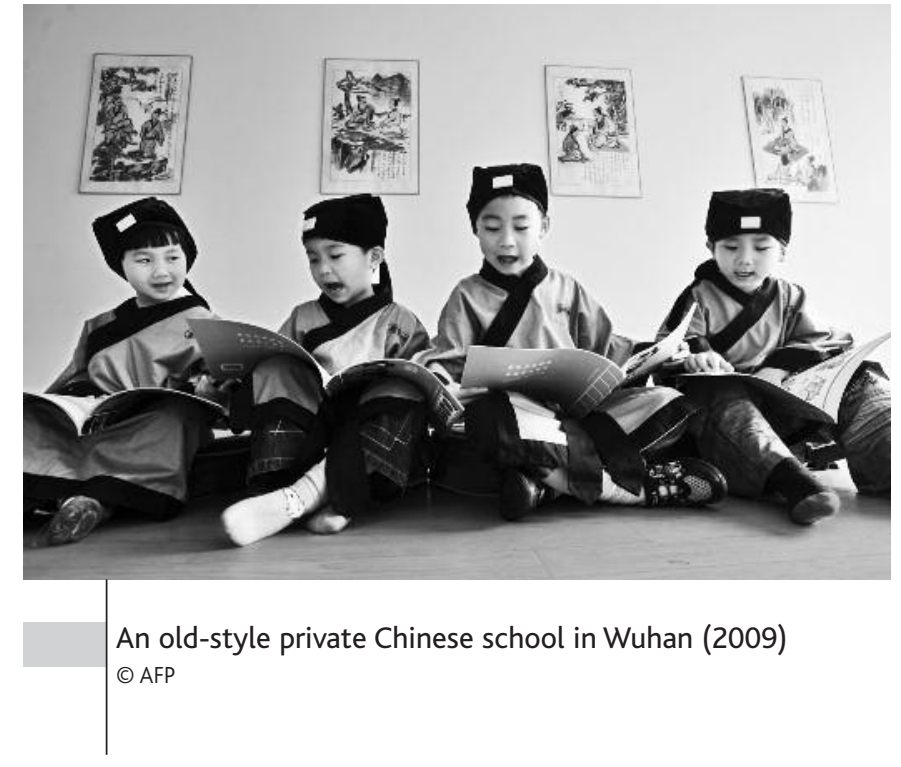

on the future of Confucian culture. That summer, a symposium on the "The Modern Fate of Confucianism," lauded as "a summit meeting of cultural conservatives," was held in Guiyang. This series of events made 2004 a year that further stoked the fires of national studies fever.

Beginning in 2005, the establishment of a "national studies institute" at Renmin (人民) University spread the national studies craze to educational circles. One after another, Tsinghua (清華) University, Xiamen (廈門) University, Wuhan University, and other tertiary institutions revived or established national studies institutes. Several of them even recruited full sets of national studies undergraduate and graduate students, then applied to the Ministry of Education to classify national studies as a first-class discipline, of equivalent ranking with disciplines such as philosophy, history, language, and history.

Yi Zhongtian's (易中天) "Commentary on the Three Kingdoms" and Yu Dan's (于丹) "About The Analects," aired on CCTV's "Lecture Room" (百家講壇, Baijia Jiangtan) program, became sensations and spread the national studies craze further into the public sphere. National studies courses mushroomed throughout the country, and popular books relating to Confucianism and traditional culture became best sellers. The phenomenon of "children reading classics" also emerged, with some elementary schools (such as Hangzhou's Gongchenqiao (拱宸橋) Primary School) having their students recite from The Analects for 10 minutes every morning, noon, and evening. (4) Even some prisons (such as Guangdong's Foshan Prison) tried implementing national studies education by having prisoners perform group recitation of the Three-Character Classic and so on. ${ }^{(5)}$ The national

1. Translator's note (TN): Kuang Yaming (1906-96) was president of jilin University and published a number of works on Confucius, including A Critical Biography of Confucius in 1985. Gu Mu (1913-2006) served as Vice-Premier and as vice-chairman of the CPPCC, and dealt with China's economic construction in the 1970s and 1980s. He repeatedly promoted Confucian teachings for their practical application to China's reform.

2. TN: Fang Keli (ed.), Xiandai xinruxue jiyao congshu, Zhongguo guangbo dianshi chubanshe, published in multiple volumes starting in 1992.

3. TN: Literally, "the original way," another name for Confucianism.

4. Author's note (All notes are author's notes unless otherwise specified): See Ma Junya et al., "Ji Xianlin Ren Jiyu liqu: 'Guoxue re' fuxing haishi xuhuo?" (Ji Xianlin and Ren Jiyu depart: "National studies craze" as revival or borrowed heat?), 20 July 2009, http://bbs.beijingww.com/thread-17905-1-12.html.

5. See Yang Dazheng et al., "Foshan jianyu yong 'Guoxue re'" (Foshan Prison engulfed in "national studies craze"), Zhongguo Ningbowang, 24 November 2009, http://news.cnnb.com.cn/system/2009/ 11/24/006335718.shtml. 
studies craze also spread to business management. China's highest seat of learning, Peking University, was one of a number of prestigious universities that seized the opportunity to offer "national studies courses" that charged tuition as high as tens of thousands of yuan to help entrepreneurs absorb what was termed the "commercial wisdom" of national studies. In no time, national studies became a panacea for every conceivable ill.

\section{Controversies and criticism triggered by the national studies craze}

It should have been a matter of course for Chinese to propose studying and promoting their own traditional culture. Due to the complexity of traditional culture, however, and for particular historical and practical reasons, as well as some circumstances emerging from the craze itself, the national studies craze became a controversial issue.

\section{What are "national studies"?}

If "national studies" are to be promoted, it is necessary to first establish clearly what "national studies" include. Chen Duxiu previously raised the point that we did not really understand what national studies were. He even categorically asserted, regarding the term "national studies," that "even if we examine and revise it for 100 years, we may not succeed in obtaining a clear-cut definition, because 'national studies' has murky origins and is not a proper term." (6) One of the critical views at present likewise holds that the concept of "national studies" is applied ambiguously. I will summarise the current main uses of the term into several categories:

1) A general reference to China's intrinsic traditional culture, as opposed to Western learning and culture. Some scholars formulate it as "a country's intrinsic learning." (7) Others point to specific content, such as the Three Doctrines and Nine Schools (三教九流), including Confucianism, Buddhism and Daoism. ${ }^{\left({ }^{8}\right)}$ This is the broadest connotation and is also the most commonly used. Some scholars believe it encompasses not only the humanities and social sciences, but also the natural sciences. (9) Yet others put forward the concept of "greater China studies," which apart from Han Chinese culture includes all ethnic minority cultures that have emerged within China's historical borders. ${ }^{(10)}$

2) Referring to China's historical learning and culture. As Zhang Dainian (張岱年) puts it, "National means this country, national studies means the learning of this country, namely Chinese learning." (11)

3) Referring to "study of the Six Arts." This has been put forward by Ma Yifu and endorsed by Liu Mengxi (劉夢溪) and other scholars. ${ }^{(12)}$

The current national studies craze is mainly in the sense of the first category, that is, a traditional culture craze. But even "national studies" in this sense is very ambiguous. If "vigorously promoting national studies" meant promoting Chinese literature and arts that carry on tradition - such as reviving the popularity of listening to stories from The Three Kingdoms, listening to lectures on the Analects, appreciating traditional drama (such as Peking Opera), and even reciting passages from the classics - and enjoyment of traditional culture in this sense surged into a fad, it would not have given rise to any controversy or been fundamentally controversial. In addition, purely undertaking academic research into national studies, for instance research in "Dunhuang (敦煌) studies," would not cause any con- troversy over "legitimacy." That is because these are not really part of the core values of culture, and therefore would not conflict in any way with the so-called Western values of freedom, democracy, and justice, and consequently would not trigger questions of whether the so-called "subjectivity" and "consciousness" of Chinese culture, the "self-confidence" of the Chinese, and the actual road of China's modernisation are a form of "Westernisation." On the contrary, in terms of cultural vehicles such as literature and art, others hold to the precept that "the more it belongs to the nationality, the more it belongs to the world," approving of harmonisation between national character and global character and the implied harmonisation between Chinese culture and Western culture.

What has actually raised controversy in the national studies craze, and genuinely constitutes a problem, is the question of traditional cultural values and their function. In particular, it is the question of the values of what is generally acknowledged as the core of traditional culture, Confucianism, and its role in the process of China's modernisation, as well as the problem of Confucian fundamentalism appearing in extremist form to oppose Western culture. In the past, Guo Moruo (郭沫若) and Shen Yanbing (沈雁冰), ${ }^{(13)}$ while endorsing a reorganisation of China's national heritage, worried that this would easily play into the hands of the restoration faction and "facilitate counterattacks by the forces of old society." (14) These concerns were not, in fact, unreasonable.

\section{The value and function of national studies}

In modern and contemporary history, thinking people's affirmation of the value of national studies has primarily focused on its role in national identification and in encouraging patriotism. Zhang Taiyan (章太炎) ${ }^{(15)}$ proposed this as the objective of national studies during the late Qing and around the time of the 1911 Revolution, in a context that regarded the Manchu rulers as an "alien race." He wrote, "Why promote national essence? It is not so that people will respect Confucianism, but only so they will cherish the history of our Han race." For this reason he put forward "using the national essence to stir racial sensibilities and enhance patriotic fervour." (16) Zhang Taiyan's use of the term "patriotic" here has the connotation of resisting not only the "alien" rule of the Qing dynasty, but also "Europeanisation."

6. Ren Jianshu et al. (ed.), Chen Duxiu zhuzuo xuan (Selected works of Chen Duxiu), vol. 2, Shanghai renmin chubanshe, 1993, pp. 516-517.

7. Deng Shi, "Guoxue jiangxi ji" (Lectures in national studies), Guocui xuebao, no. 19, 20 June 1907. Quoted in Tang Zhijun's Foreword to Zhang Taiyan, Guoxue gailun (Introduction to national studies), Shanghai guji chubanshe, 1997, p. 6.

8. Li Xueqin, "Zai guoxue re zhong de ji dian sikao" (Some reflections on the national studies craze), Dongyue luncong, no. 6, 2009, p. 7.

9. Li Zonggui, "Guoxue yu shidai jingshen" (National studies and the spirit of the age), Xueshu yanjiu, no. 3, 2008, p. 21.

10. Zhu Weizheng, "Guoxue dawen" (National studies catechism), Shucheng, no. 9, 2007, pp. 7-8.

11. Zhang Dainian, "Guoxe yu shidai" (National studies and the times), Zhongguo Shehui Kexueyuan yanjiushengyuan xuebao, no. 5, 1995, p. 1.TN: Zhang Dainian is professor emeritus of philosophy at Peking University.

12. Liu Mengxi, "Xiandaixing yao he chuantong huxiang pipan" (Modernism needs mutual criticism with tradition), Shehui kexue luntan, No. 8, 2008, p. 115. TN: Ma Yifu (1883-1967) was a noted classical scholar. Liu Mengxi is director of the Institute of Chinese Culture of the Chinese National Academy of Arts. The Six Arts of ancient Chinese culture are rites, music, archery, charioteering, calligraphy, and mathematics.

13. TN: Guo Moruo (1892-1978) and Shen Yanbing (1896-1981), better known by his pen name, Mao Dun (茅盾), were prominent authors of the Revolutionary and post-Revolutionary period.

14. Quoted in Deng Shaoji, "Wo guan 'guoxue re"' (My view of the "national studies craze"), Zhongguo Shehui Kexueyaun yanjiushengyuan xuebao, no. 5, 1995, p. 3.

15. TN: Born Zhang Binglin (章炳麟, 1868-1936), a Chinese philologist, textual critic and anti-Manchu revolutionary. 
Where, then, is the value of national studies in contemporary society? Scholars encouraging the promotion of Confucianism enumerate the following main values for which Confucianism can serve as a modern intellectual resource: the view of man at harmony with and as an integral part of nature; the moral law of "not doing unto others what you would not have done unto yourself"; and the emphasis on harmony as a principle of social conduct. For example, Peking University professor Tang Yijie's essays propose that in regard to the three major problems existing in human society - that is, the relationship between man and nature, the relation between individuals, and the relationship between an individual's body and mind - Confucianism's three philosophical propositions of "unity of man with nature (or Heaven)," "unity of self with others," and "unity of body and mind" offer a valuable train of thought and an intellectual resource of particular importance. The leading exponent of Neo-Confucianism overseas, Tu Weiming, has put forward this question for consideration: If the world required reorganisation, could Confucianism serve as "a new value" and "offer some spiritual resources" to replace the ultra-competitive social Darwinism and the law-of-the-jungle hegemony represented by the West?

In mainland China, a relatively common viewpoint at present is that under the current conditions of China's gradual rise in strength and prosperity, reviving national studies facilitates "raising cultural consciousness, recovering cultural self-confidence, achieving cultural identification, and enhancing the cohesive force of nationalism," which in turn facilitates "raising ethical standards among the Chinese, promoting their cultural accomplishments, and building a harmonious society, which will ultimately facilitate "enhancing China's cultural competitiveness and promoting its international influence." (17)

What is regrettable is that among the values and relevance the aforementioned scholars suggest that Confucianism can offer to contemporary society, we see nothing that today's Chinese society urgently needs - that is, the values needed to build a modern society, such as human rights, democracy, and justice. To borrow current political terminology, the modern conceptual resources of Confucianism listed above do not touch on humanity's "core values"; or in other words, in terms of human existence and its attendant social laws and institutions, the values Confucianism can offer the present age are not the most central or fundamental. Freedom, justice, democracy, and rule of law are the most central values, and they are the prerequisite conditions for the establishment of a modern society. As for the relationship between man and nature, between individuals, and between body and spirit, it is only under an optimal system with democracy and rule of law, and in which an individual's rights are fully safeguarded, that these can be brought to full fruition. Unfortunately, these core values do not appear among the values of traditional culture that others have mentioned.

For this reason, some opposing voices have emerged in the midst of the national studies craze. Regarding the status of national studies in contemporary China, Nankai (南開) University Professor Liu Zehua (劉澤華) and others have taken the view that the process of China's modernisation has put national studies in a "helpless and marginalised" position, and that this in fact demonstrates "the progress of history" and the immutable "choice of history" that cannot be diverted by subjective will. (18) Professor Chen Lemin (陳樂民) of the Chinese Academy of Social Sciences has unequivocally opposed raising up national studies (or "old studies") in a time of reform and opening. He categorically asserts that so-called "national studies" has gone in and out of vogue from the late Qing to the present, and that it "early on ran out of steam" and has not been able to accomplish anything of significance. He quotes Wen Yiduo (聞一多) (19) as saying, "After living among piles of musty old books and papers for more than 10 years, I have gained a firm grasp of the ills of our people and this culture, and I dare to write a prescription." Chen Lemin believes that the prescription referred to here was "the ideal of democracy and freedom." He counters with the question of whether "old studies" or "national studies" could accomplish this task. If not, then it was simply preposterous, in this time of reform and opening, to wheel out national studies that represent a retreat back in time. In a similar vein, some scholars hold that Confucian doctrine was negated back during the May Fourth movement, and that to restore it now to such high esteem is historical reversionism, etc., etc.

Some commentators, while not denying the modern relevance of national studies, point out the limitations of this relevance, namely, that it can play only a sideline role in China's modernisation. For example, the director of Peking University's Chinese Studies Institute, Yuan Xingpei (袁行需), points out, "What will genuinely save China and guide China toward modernisation is not national studies," although he believes that in China's progress toward modernisation, national studies can serve a "promotional function." (20) This implies that in terms of China's modernisation, national studies serves only a supplementary function.

\section{Is the national studies craze "artificial heat"?}

Commercial speculation and other such activities accompanying the national studies craze are another focus of criticism in the media. Because some prominent universities have used "national studies" as an excuse to offer high-tuition commercial "national studies" courses, and equally numerous and profitable children's "national studies classes" have been set up throughout the country, these methods using national studies for the pursuit of profit have aroused antipathy in society, incurring more than a little criticism that this is a vulgar commercial activity, or that the national studies fever is a form of "artificial heat" (21) that can only be considered part of a popular cultural propagation campaign that has not attained any meaningful academic level.

For example, some articles have depicted the phenomenon in a critical way: "In the current market economy environment, all kinds of commercial powers are engaging in speculative 'national studies' activities that change its character. Dedication to work and a sense of responsibility have paled, and manipulation and engineering and other such methods have been fully utilised, with market value and a consciousness of fame and wealth coming to the forefront and becoming the objective. So 'national studies' speculation is essentially a kind of commercial activity rather than a 'national studies' activity. It turns out that profound, uplifting, remote, mysterious

16. Tang Zhijun (ed.), Zhang Dayan zhenglun xuanji (Selected political commentaries of Zhang Dayan), vol. 1, Beijing, Zhonghua shuju, 1977, p. 272.

17. Ji Baocheng, "Cuoxue hewei" (What is national studies), Guangming Daily, 21 July 2008, quoted in Ruxue yaobao, no. 124, p. 10.

18. Liu Zehua et al., "Ba guoxue liewei yiji xueke butuo" (Inappropriate to make national studies a firstclass discipline), Zhongguo shehui kexuebao, 11 February 2010, quoted in Ruxue youbao, no. 122, p. 21.

19. TN:Wen Yiduo (1899-1946) was a leading poet of the 1920s killed by KMT right-wingers for criticising the government.

20. Yuan Xingpei, "Cuoxue de dangdai xingtai yu dangdai yiyi" (The modern form and significance of national studies), in Makesizhuyi yanjiu, no. 10, 2008, pp. 71-72.

21. TN: The term in traditional Chinese medicine for a condition of "yin deficiency" has the alternative meaning of relying on someone else's power or influence. 
national studies and traditional cultural classics can be made as 'theatrical,' entertaining, and comical as Qing palace dramas (22)... Since starting 'national studies courses' in Shanghai geared toward entrepreneurs, Fudan and Tsinghua [universities] are scrambling for students. Tsinghua's 'national studies course' charges tuition of 26,000 yuan, while Fudan charges 38,000 yuan per year. Fudan University's College of Management has also started an 'Outstanding Women's Curriculum,' which claims to use 'national studies' essentials to help imbue successful women with the personal charm of Oriental women.... This kind of entrepreneur-oriented 'national studies course' - costly, removed from the ordinary people, and removed from mass education - has become 'national studies' for dilettantes." (23)

Some writers sharply criticise this kind of national studies speculation for making national studies into the ultimate "luxury item" and target of extravagant spending. It has become "Monk Tang's flesh," (24) with everyone wanting a bite. The national studies craze has become an amusement, and enhancing national studies has become a front for the ultimate objective of pursuing economic profit. (25)

Some media reports have employed a sarcastic tone in their depictions of children reading Confucian classics:

"The Standards for Students / were taught by the sages / First is filial and fraternal duty / next is to be careful and trustworthy...." $A$ dozen children dressed in traditional Chinese garb sit ramrod straight, their eyes fixed forward, and with bobbing heads loudly accompany their teacher reciting the Standards for Students. A portrait of Confucius hangs on the teacher's wall, and ancient tunes flow gently from a tape-recorder in the corner. This is a typical classroom in many of today's "national studies instruction halls."(26)

The method of "children reading classics" also emerged after the 1911 Revolution. For example, Yuan Shikai (袁世凱), who planned to restore the monarchy, at one point ordered the resumption of reading the classics in primary and secondary schools. During the Japanese puppet regime, primary and secondary school students were required to read the Classic of Filial Piety, The Analects, Mencius, the Book of Rites and other classics every week. Zhu Ziqing (朱自清) (27) said of this, "Although there have been one or two campaigns to have primary and secondary students read the classics since the Republican era, they were unsuccessful; people considered them turning back the wheels of history." (28) History often produces astonishing resemblances. Some people will inevitably ask whether current activities are likewise "turning back the wheels of history."

Regarding the phenomenon of young children reading classics, Sun Yatsen University professor Yuan Weishi (袁偉時) attacked it without even a veneer of courtesy: "If the classics-reading movement were strictly voluntary, it would give little cause for criticism. But they want to take the old road of the warlords of the early twentieth century, forcing children to read the classics, which is extremely foolish and wrong." (29)

\section{"Confucian fundamentalism" in the national studies craze}

The most extreme thinking in the national studies craze has come from particular individuals among the "Confucian fundamentalists." Their leading exponent, Jiang Qing (蔣慶), (30) renders the following basic judgment of China's current reality: China's political and legal concepts and systems are becoming progressively Westernised, and China, "in terms of its political and legal concepts and system, has already become a colony of Western culture and Western learning." He even goes so far as to offer as "clear proof" of this judgment "the widespread faith in freedom and human rights among the Chinese, and the state's advocacy of democracy and rule of law." (31)

Generally speaking, Chinese regard "freedom and human rights" and "democracy and rule of law" as positive values - they're good things. Yet Jiang Qing offers them as proof that China has become colonised by Western culture. By that logic it could be said that anything from the West is bad. At this point we are compelled to respond by asking: if "freedom and human rights" and "democracy and rule of law" must be negated, does that mean that only their opposite - despotism - can be called a good thing?

Based on the aforementioned judgment that China has already been colonised by Western culture, Jiang Qing preaches the revival of Confucianism to counter Western culture. He proposes an entire program for reviving Confucianism and using it to resolve all of China's problems - political, social, and in daily life. The main points of this program include:

1) Making Confucianism the state religion and state ideology. China would implement a political system allying religion (Confucianism) and state in which the state would take on the responsibility of moral education.

2) Establishing a system of "Confucian constitutional government" and making Confucianism the foundation of the state regime's legitimacy.

3) Re-establishing the imperial civil service examination system and classical education, with The Four Books and The Five Classics serving as basic textbooks for primary and secondary school, and with government employment requiring passing an exam on The Four Books and The Five Classics.

22. TN: Apparently referring to a trend since the 1980 s to produce television series centred on the life of the Qing emperors and those around them. The dramas could be serious or humorous, factual or fictional.

23. Liu Xiaolin, "Zheyang de guoxue re keyi ma" (Is this kind of national studies acceptable?), Guancha yu sikao, no. 8, 2007, posted on Xinhua Net, 19 April 2007, http://news.xinhuanet.com/book/200704/19/content_5998875.htm.

24. TN: Referring to Tang Xuanzang, the monk chosen by Buddha to go with others to India to obtain the Buddhist scriptures in The Journey to the West. In the novel, it is said that anyone who eats the monk's flesh will become immortal, so every demon the group encounters tries to eat Monk Tang. In modern parlance, the term refers to a lucrative opportunity that everyone wants to get in on.

25. Li Huahui, "Guoxue re yi xu leng sikao" (National studies craze requires cool reflection), Zhongguo jiaoyubao, no. 11, 20 March 2007, quoted at Guanggong zaixin, 20 March 2007, http://online.gxut.edu.cn/sxtd/sdjd/ 20071108/11786.html.

26. Ma Junya et al., "Ji Xianlin Ren Jiyu liqu...," op. cit.

27. TN: Zhu (1898-1948) was a pioneer of modernism during the May Fourth Movement.

28. Zhu Ziqing, "Jingdian changtan" (Classical platitudes), see San Dashi tan guoxue (Three great scholars comment on national studies), Shanghai sanlian shudian, 2007, p. 195.

29. Yuan Weishi, "Guoxue re he xinzuopai jiemeng bu shi hao xianxiang" (National studies craze alliance with the New Left is not a positive development), quoted at Haoyawang, 24 August 2007, http://www.haoyah.com/ main/html/namuzhenxiang/ 20070824/264.html.

30. Author of Political Confucianism and operator of a Confucian academy in Guizhou Province, Jiang Qing argues that Confucianism is more appropriate for contemporary China than Western-style liberal democracy. See Daniel A. Bell, "China's Leaders Rediscover Confucianism," International Herald Tribune, 14 September 2006, http://www.nytimes.com/2006/09/14/opinion/14iht-edbell.2807200.html, and by the same author, "A Visit to a Confucian Academy, Dissent Magazine, 22 September 2008, http://www.dissentmagazine.org/online.php?id=146.

31. Jiang Qing, "Fuxing Ruxue de liang da chuantong - 'zhengzhi Ruxue' yu 'xinxing Ruxue' de chongjian" (Reviving two Confucian traditions - rebuilding "political Confucianism" and "mental Confucianism"), 20 July 2010, at http://new.21ccom.net/plus/view.php?aid=3639

32. Xie Qingtong, "Bei niuqu de Rujia jingshen haiyou duoda jiazhi" (How much value is there in a distorted spirit of Confucianism?), posted on Zhongguowang, 7 September 2006, http://www.china .com.cn/authority/txt/2006-09/07/content_7140478.htm. 
These stands by Confucian fundamentalists (原呚旨主義者, yuanjiao zhi zhuyizhe) have met with a largely critical response. China's ideologically enlightened citizens are able to discriminate among ideas, and are no longer as gullible as they once were. Criticisms of Confucian fundamentalists posted on the Internet express quite reasonable viewpoints. For example, a commentary from Eastern Morning Post (方早報, Dongfang Zaobao) says that at present "Confucian fundamentalists magnify the virtues of traditional Chinese culture, then go on to magnify the shortcomings of Western culture." (32) Another online essay states: "The movement to oppose democratic politics and revive monarchy thoroughly destroys the credibility of Jiang Qing's Confucian revival." (33) These criticisms strike at the heart of Confucian fundamentalism.

Given that the agenda of Confucian fundamentalism is rooted in the past, it has inevitably met with criticism from scholars of various schools of thought. The objections voiced by scholars of the Liberalism school are: The idea of "Confucianism saving China" is reactionary to modern democratic government and tramples on the concept of "equality." Establishing Confucianism as "state religion" would make China into a Confucian version of Iran and constitute "an attempt to turn Confucianism into ideology in the service of despotism." Some Liberal scholars offer the further criticism that promoting a political Confucianism - attempting to "use the political wisdom and guiding principles of Confucianism to transform China's political reality and establish in China a political order that gains its legitimacy from the Way of Heaven" - essentially opposes the modern democratic politics of equality of all before the law and universal suffrage, and insists on an obscurantism that puts "the intelligent over the ignorant" and "gentlemen over those of low estate" and gives sages the innate power to instruct the common people while giving ordinary people no power to utilise rational analysis. "This absurd proposition will only serve as a kiss of death to carrying on and enhancing traditional thinking and culture." (34)

Marxist scholars offer the following refutations to Confucian fundamentalism: "The fanciful notion of Confucianism saving the world is essentially self-aggrandisement of one's moral role." It is also "using the metaphysics of the Way of Heaven and principle of nature in the pursuit of kingly politics, which can only fall back into the trap of feudal autocracy." "The world's salvation lies only in Marxism." (35)

Even scholars in the Confucian camp oppose the extremist stands taken by Confucian fundamentalists. For example, a Confucian scholar at Sichuan University, Huang Yushun (黃玉順), has written that he is "of one voice" with Confucian fundamentalists in their stands on national culture and opposing Westernisation, but that in regards to their "rejection of all so-called 'Western' things and rejection of all basic 'achievements of human civilisation,"' including the rejection of developing democracy and science and even opposition to science, he "begs to differ." (36)

\section{The national studies craze from the angle of universality}

As conflicts with Western civilisation have emerged in recent times and centred on the question of where China is going, traditional Chinese culture's relationship with modern culture has become a crucial issue vexing China's thinkers. On the one hand, the largely Confucian traditional culture cannot provide values and theories of modernisation such as market economics and democratic politics. On the other hand, the concepts and values that can be learned from the West make some people apprehensive that China will sink into Westernisation. For that reason, the real quandary for China's thinkers has been in finding a way to satisfy both sides by allowing China to implement modernisation like the developed countries of the West, while at the same time preserving China's traditional culture. From the late Qing up until the late twentieth century, controversy over this point was typically embodied in well-known propositions such as "Chinese for essence and Western for utility" or "Western for essence and Chinese for utility." The current national studies craze is in fact a specific manifestation of this debate, and is the particular reverberation of that old question in a new era.

The grounds the current national studies craze puts forward for "vigorously developing national studies" are therefore mainly related to competition or contention with "Western studies" or Western culture. This can be divided into two aspects. "Cultural Confucianism" in a general cultural sense focuses on raising a national cultural consciousness, reviving cultural selfconfidence, bringing about cultural identification, and defending the "subjectivity" of Chinese culture. In terms of the "political Confucianism" of Confucian fundamentalism, the goal of "reviving Confucianism" is to "respond to the comprehensive challenges posed by Western civilisation" in order to "rebuild Chinese civilisation," and to use Confucianism to comprehensively "resolve China's political problems, social problems, and problems of the people's livelihood." (37) These two ways of thinking have a common background and confront a common question: As China rises to the status of a great nation, what position should traditional culture hold in our people's current and subsequent development, and how should the relationship between national character and modern character be managed?

Since the 1990s, with the growth of China's economy and general strength and prosperity, nationalism has leapt to the fore as a major social trend in China. It is manifested in a variety of forms, sometimes quite fanatical. The national studies craze has served to boost nationalism. The combination of national studies with nationalism is reflected in attempts to use a nationalism based on Confucian culture as a socially integrated resource for China's modernisation. For example, Shanghai Normal University professor Xiao Gongqin (蕭功秦) calls for a nationalism based on the mainstream culture of Confucianism to serve as a new ideological resource for China's transition. He holds that "Under the new historical conditions, seeking new resources to legitimise power so as to achieve coalescence and integration in the process of social transformation is a major problem that China's modernisation is currently facing." (38) In his view, because Confucianism in the 1990s already had no "anti-modern" qualities, it had the capacity to provide this kind of ideological resource.

33. Huang Yingquan, "Zhen Ru hezai? - Zai ping Jiang Qing" (Where is the real Confucianism? Another criticism of Jiang Qing), 26 July 2007, http://www.cssm.gov.cn/view.php?id=10509.

34. Xu Youyu, "Zhongguo sixiangjie 30 nian fenhua yu liubian: Geju yi bu luo chuantong kejiu" (Divisions and diversions among Chinese intellectuals over the last 30 years: Pattern doesn't fit the traditional stereotype), 2 September 2009, http://www.sociology.cass.cn/shxw/zl/t20081212_19712.htm.

35. See Tang Yijie (湯一介), "Ruxue de xiandai yiyi" (Confucianism's modern significance), in Daguoce Tongxiang daguo zhi lu de Zhongguo ruan shili: Guoxue re yu wenhua chuancheng (Great nation policy - The soft power of China on the road to Great Nation status: The national studies craze and carrying on cultural heritage), Renmin ribao chubanshe, May 2009.

36. Huang Yushun, "Ruxue yu shenghuo: Minzuxing yu xiandaixing wenti" (Confucianism and life: The question of national character and modern character), posted on Zhongguo Ruxuewang, http://www.confuchina.com/00\%20zhuye/Collected\%20Works/11\%20Lunji/51.htm (accessed 14 January 2011). .

37. Jiang Qing, "Guanyu chongjian Zhongguo Rujiao de gouxiang" (Rebuilding the conceptualisation of Chinese Confucianism), posted on the Kongzi 2000 nian website, http://www.confucius2000.com/ admin/list.asp?id=2149 (accessed 14 January 2011).

38. Xiao Congqin, "Minzuzhuyi yu Zhongguo zhuanxing shiqi de yishi xingtai" (Nationalism and the ideology of China in transition), Zhanlüe yu guanli, no. 4, 1994, pp. 23-24. 
The nationalism displayed in the cultural sphere against the backdrop of the national studies craze - "cultural nationalism" - takes the basic stance that Western civilisation is currently facing an irresolvable spiritual and cultural crisis, and only Eastern culture can rescue the world from this crisis. For this reason, the twentieth century was the century of Chinese culture. A prominent Peking University professor, Ji Xianlin (季羡林), is a leading proponent of this viewpoint. The grounds for his argument are that every civilisation experiences its periods of rise and fall - or in the words of the Chinese proverb, the river flows east for 30 years and then west for 30 years, wind and water flowing in alternating directions over time. Hence, the historical replacement of decadent Western culture with flourishing Eastern culture is at hand. Some scholars dismiss ji Xianlin's viewpoint as a crude "fengshui" theory not even worth refuting. One extreme demand of cultural nationalism is to enshrine Confucianism as state religion in the Constitution.

For any national group, nationalism has always served a two-fold purpose. On the one hand, it can generate a national and cultural identification that enhances social cohesive force and stimulates patriotic fervour. On the other hand, it can easily be utilised as a behavioural criterion unmoored from any grounds of scientific principle, inciting blind feelings of vengeance and parochialism against the Other is one of its manifestations. However, the social progress brought by reform and opening, the experience and lessons of history, the enlightenment of thought and culture, and an increased understanding of the outside world have combined to make today's Chinese much more rational. One awakened realisation is of the danger of getting bogged down in parochial nationalism; it "brings about an intensely xenophobic mentality, and cannot genuinely and thoroughly absorb the strong points of other nations' cultures - in particular absorb and adapt to modernisation and adapt to the cultural resources required by modern society." (39) For that reason, the national studies craze needs to guard against a tendency toward parochial nationalism. It is the natural enemy of China's opening, especially in a situation in which Chinese society currently lacks a mechanism of checks and balances.

Another major problem related to the national studies craze is the issue of the modernity of China. Can reliance on Confucian traditional culture lead China to achieve modernisation? The only possible answer is no. What has China relied on to achieve the progress it has made over 30 years of reform and opening? Clearly it has not relied on the traditional culture of Confucianism as its ideological resource. Given that Confucianism is a long-established ancient doctrine and culture, if it were able to push forward the process of China's modernisation, it would have done so long ago, and modern China would not have been placed in its tragic position combining feudalism with colonialism.

Why was Confucianism unable to promote modernisation? This no doubt involves a number of complicated historical, political, social, and economic factors, but Confucianism's intrinsic lack of modern values must be considered one of them. And what exactly are "modern values"? The rights of human beings, including the rights to freedom, property, and life, as well as the concepts of democracy and rule of law - these constitute basic modern values, and these are exactly what Confucianism lacks. The core values of Confucianism - benevolence, righteousness, loyalty, filial piety, etc. ${ }^{(40)}$ all relate to a person's responsibilities and obligations, rather than to a person's rights. That is to say, Confucianism is fundamentally a theory of inequality - the inequality of rights to obligations. All it requires of people is the fulfilling of their duties, a paying "upward" (to the monarch, leader, etc.), without affirming or protecting an individual's rights. Yet modern society is built on the foundation of individual rights being explicitly affirmed and protected. In addition, in terms of governance, Confucianism's concepts and methods are based on "personal rule," and the disastrous results of this kind of governance are still being experienced in our society to the present day. The current social injustice, corruption, and other problems in today's Chinese society did not, as diagnosed by the New Left, originate in capitalism under globalisation or multinational companies, but rather, for the most part, in defects in the political and economic system, and that is what has brought about problems such as the authorities not coming under supervision or restraint and their involvement in rent-seeking behaviour. The government has become an economic special interest group; power and capital conspire and officials and businessmen collude to misappropriate and plunder society's wealth, resulting in social injustice. The lack of supervision or restraint of the authorities is in fact a manifestation of society under "personal rule." In this sense it can be said that the negative influence of traditional Confucian society still exists, and this influence is incompatible with modern rule-of-law society. For this reason, whether in terms of values or governance concepts, Confucianism must be considered incompatible with modern society, and it is therefore unreasonable to artificially elevate Confucianism.

How to regard and evaluate the current national studies craze - this in itself constitutes one of the points of debate in the national studies craze. Evaluation of any matter can be carried out from any number of angles, such as truth, virtue, fairness, legitimacy, reasonableness, etc. Comparatively speaking, the concept of "reasonableness" is clearly the most appropriate standard for evaluating the national studies craze. In order to say whether something is reasonable or not, we need to examine its pros and cons. In terms of a culture, "pros" include its progressiveness - whether or not it can promote rather than hinder social progress. The reasons put forward for vigorously promoting national studies are for the most part made from the national-ethnic standpoint rather than from the standpoint of humanity as a whole. In philosophical terms, this touches upon the relationship between "particularity" and "universality." Just as we speak of or regard someone on the basis of whether that person is a Shanghainese, a Chinese, an Asian, or just a human being, we can speak of or regard a culture in the same way. We can use the "Shanghainese" angle to regard a particular person, and according to the criteria of that particular angle design and develop that person's distinguishing features, for instance having him speak Shanghai dialect, learn to sing Shanghai opera, gain proficiency in Shanghai's history and culture, follow Shanghainese conventions in all his actions, and become a classic Shanghainese. This is one way of training up a person from the angle of "particularity." No doubt some "distinctive character" will result from such training, but ultimately it will be difficult to achieve a worthwhile result. On the other hand, we can develop him from the angle of "universality," which is to say, we can foster universal human qualities, and through education and training enhance his rationality, and breed in him a noble character that aims to serve the cause of human progress in a spirit of internationalism. Very few people are likely to negate

39. Tang Yijie, quoted in "Wenhua minzuzhuyi... Ziyouzhuyi dui guoxue re de kanfa" (Cultural nationalism... Liberal views of the national studies craze), 28 May 2003, see http://bbs.1931-918.org/viewthread.php?tid=13896.

40. For example, Tu Weiming writes, "The core values of Confucianism — benevolence, righteousness, rites, intelligence, trustworthiness." See his "Rujia chuantong de xiandai zhuanhua" (The modern transformation of Confucian tradition) in Jing Haifeng (景海峰) (ed.), Chuanxinji (Passing on the torch of learning), Beijing daxue chubanshe, 2004, p. 415. 
this latter form of training, because it involves enhancing a person's universalist orientation. Likewise, there are two main forms of cultural development: should we limit ourselves to approaching our national culture from the angle of particularities, or use the angle of universality to enhance our national culture? Are those things with particular characteristics necessarily "national essence" and invariably good? Wasn't the foot-binding of women a distinguishing characteristic? It can be seen that things with particular characteristics can be a matter of chance, while only the universal is inevitable, because it constitutes the essential part of the particular. Of course, this is not to say that universality is absolute or to separate it from particularity; universality depends for its existence on the exceptional. Rather, what we emphasise is that the particular should not be made an absolute; the particular should be elevated to the universal in order for it to avoid, as much as possible, becoming a matter of chance.

In the course of history, each national ethnicity has formed its own particular culture. At the same time, however, these cultures have in various degrees and to various extents risen toward universality. The more a culture approaches the quality of universality, the firmer the grasp it gains on the inexorable law of cultural development, the more advanced that culture will become, and the farther ahead of other cultures it will advance, even in an era that endorses cultural pluralism. This is the logic revealed in the saying "World trends are vast and mighty; those who follow them prosper, while those who go contrary to them perish." The world trend is essentially universalist; it is not something that can be transformed by a particular aspiration. Only a culture that flows with this tide and joins or even guides the universal culture is a vital culture. This means that a particular culture cannot limit itself to chance, but must in its specialness grab hold of the universal, grab hold of the inevitable, in order to position itself at the forefront of the historical trend.

Doing this requires creativity, and creativity is inseparable from discovering problems. In a very real sense, discovering problems is achieved through scepticism and criticism regarding existing learning and culture. The ancients said, "Better to have no books than to believe them unreservedly," (41) while Westerners say that existing knowledge should be treated with "suspension of judgment"; ${ }^{(42)}$ both are saying the same thing, which is that existing thinking and knowledge should be treated with scepticism and that one should avoid being influenced by it as much as possible. If we accept this point, then in terms of frame of mind, raising slogans such as "reviving national studies" does not facilitate the cultivation of a spirit of scepticism or criticism, nor does it facilitate the development of thinking, learning, and culture, because the thinking behind this proposition is the very opposite of sceptical or critical, and can easily give rise to a blind affirmation of traditional things, or even blind worship. Just think: how can a person who from his youth has regarded the Confucian classics as the "books of the sages" turn into a person who regards these works with scepticism or criticism? And without the prerequisite of scepticism and criticism, it is very hard to discover problems, as a result of which thinking and learning become very hard to push forward.

In terms of the history of Chinese thought and learning, what is lacking is not an affirmation of traditional culture, but on the contrary a lack of scepticism and criticism toward it. Of course, the "scepticism and criticism" referred to here is well-intentioned and meant in the sense of discovering and solving problems, rather than outright negation. In terms of Confucianism, what scholars have been thinking since ancient times - to borrow Feng Youlan's ${ }^{(43)}$ words - is how to "follow on from it" or "carry it forward." Although he meant "carry it forward" in the sense of saying something new, why can we only "follow" or "carry" rather than initiate a new discourse and open up a new philosophy? Why, after Confucianism, could there only be "Neo-Confucianisms" succeeding one other in each new era? Speaking of Confucian orthodoxy and orthodox tradition and the "orthodox school" as standard and glorious ${ }^{(44)}$ makes it seem as if the only Chinese philosophy allowed throughout the ages was Confucianism. Heaven does not change, and neither does the Way. ${ }^{(45)}$ Referring back to the West, we see realism, apriorism, phenomenology, existentialism, analytic philosophy, structuralism, deconstructionism... and there are many others that could be cited. By Confucian standards, which one is orthodox? Therefore, in contrasting the experiences in thought of Eastern and Western philosophy, innovation and creativity in learning and culture require first of all scepticism and criticism, and through discovering problems and finding new problem areas, creating new understanding and explanations to form new thinking or even a school of thought. These should be the scientific parameters of scholarly development from the outset. The Chinese culture of the Spring and Autumn period became the most brilliant and magnificent period in China's intellectual history, not because it "respected only Confucianism" but because it let "a hundred schools of thought contend." In addition, in terms of the experience of Western thought, Kant's philosophy has been so enduring because he pondered the question of "what it is to be human," and not because he was trying to carry forward Germany's "national studies" or the philosophical traditions of the West. On the contrary, advances in Western philosophy have been built on the constant criticism of its existing traditions, as revealed in the titles of Kant's three great "Critiques." Kant furthermore completely negated all the "metaphysics" that came before him, considering them "unscientific" and requiring criticism to re-establish a "scientific metaphysics." It is this kind of critique that has enabled Western philosophy to continually produce new ideas. Even the "Renaissance" was not merely a revival of Ancient Greek and Roman culture, but rather a humanistic philosophical and cultural movement - a movement of unprecedented ideological and spiritual emancipation and creativity. It impelled a return to humanity and an emphasis on human dignity, both of which laid the foundation for the human rights thought of the Enlightenment.

Scholarly criticism serves the same purpose as a doctor's diagnosis and treatment of a patient. If we never carry out critiques of learning and culture, how can we discover their problems and shortcomings, and how can we push them forward? For instance, if we never critique society, how can we know what abuses and risks exist? Discovering problems through critique, and posing theories and methods to solve these problems, is not only theoretically creative, but also brings about progress in thinking and society, and culture develops correspondingly.

41. TN: "It would be better to be without the Book of History than to give entire credit to it." Mencius, Jin Xin II:49, as translated at Chinese Text Project, http://ctext.org/.

42. TN: The author is apparently referring to Husserl's use of "phenomenological reduction" to define the pure essence of a psychological phenomenon. Husserl used the term epoche (Greek for "a cessation") to refer to this suspension of judgment regarding the true nature of reality.

43. TN: Feng Youlan aka Fung Yu-Lan (1895-1990) was a philosopher and author of History of Chinese Philosophy.

44. For example, Han Yu proposed passing down an orthodox version of Confucianism, and Mou Zongsan continued this thinking by pronouncing Wang Yangming's philosophy as "orthodox" Confucianism, while dismissing Zhu Xi's philosophy as a "branch." TN: Han Yu (768-824) was a Tang philosopher, and Mou Zongsan (1909-1995) was an influential Neo-Confucian.

45. TN: A quote by Dong Zhongshu (董仲舒), a Western Han philosopher who institutionalised Confucianism. 
As early as 1902, Huang Zunxian (黃遵憲) (46) opposed publishing a national studies journal and opposed the promotion of national essence in China. The reason was that he believed China's problem was not in its incapacity for conservatism, but rather that "the illness is in arrogance and adherence to the old ways." (47) This viewpoint really hits the mark and points to the crux of the problem. The blind self-importance and self-deceit with which traditional culture is approached, and the wish to carry forward Confucian tradition without knowing how to actually do so, has resulted in focusing on the same old questions and topics for years on end and never setting off on a new path. A classic example is Mou Zongsan's ${ }^{(48)}$ "new inner sageliness and new outer kingliness," which strives to open a path for so-called "science" and "democracy" through the old traditional Confucian proposition of "inner sageliness and outer kingliness." In fact, the crux of the problems we face nowadays is no longer the theoretical or practical possibility of science and democracy, but rather how to effectively develop science, and how to implement genuine democracy and deal with the shortcomings that have already been discovered in the democratic system. Mou Zongsan's strenuous expounding and proving of the new inner sageliness and new outer kingliness therefore results in nothing so much as the impression of "scratching one's foot through a boot."

One phenomenon worth pondering is the modern fate of the world's "four great ancient civilisations" - ancient China, ancient India, ancient Egypt, and ancient Babylon (in fact, "ancient Greece" should also be added to make five great ancient civilisations). Did their status as the launch pads of civilisation and their long-standing and glorious traditions result in their remaining at the forefront of all the world's nations? In fact, the opposite is true. Compared with modern developed countries, every one of these is still considered a developing country - and indeed, Babylon has long ceased to exist as a country. Their glory belongs to the past, but history is changing. If tradition is not handled properly, it can become a heavy burden and an obstacle to accepting new thinking, new things, and new culture.

In the present national studies craze, what is particularly absurd is Confucian fundamentalism. Based on the absurd premise that "modern China has already 'turned to the ways of the barbarians' and been reduced to a colony of Western civilisation," it attempts to draw an equally absurd conclusion by offering "Confucianism to solve all of China's problems," including political, social, and livelihood problems. All fundamentalist religions have their similarities. For example, the Islamic fundamentalism represented by Khomeini in Iran advocates returning to the Koran.

The arguments of Confucian fundamentalism give me the impression of being full of religious fervour and taking no account of the realities of China. For this reason, it is impossible for it to succeed, but as an extremist ideology, it should keep us on the alert. The reason that Confucian fundamentalism cannot succeed is that it violates historical logic and does not realise that history cannot go backwards, and therefore is fated to be as short-lived as Yuan Shikai's attempt to restore the monarchy. Confucianism was originally a ruling ideology, but history has forsaken it because it was unable to establish a reasonable system. Yet Confucian fundamentalism's advocacy of a "wholesale revival" of Confucianism as a consummate pattern for religion and politics has as its guiding principle a wholesale return to the past and advocacy of uniting politics and religion. In the contemporary world, the only places still uniting church and state are the Vatican, Iran, and a handful of other theocracies. After comparing the virtues and shortcomings of these countries with those of democratic countries, no more need be said. If, in accordance with the aforementioned guiding principle of Confucian fundamentalism, a religious form of Confucianism really became the foundation of the country's legitimacy, the result would be a reversion to rule under a mixture of theocracy and feudalism; democracy, freedom, and social justice would be reduced to nothing more than a dream, and the series of urgent problems that China currently faces, such as corruption and social injustice, would be hard to eradicate. The scope of China's actual changes and the complexity of its situation make simply resorting to traditional Confucian culture all the more unfeasible. The "Confucian socialism" that the New Left and Neo-Confucians have jointly proposed puts "human sentiment and affection for homeland" in the same category as freedom and equality, and through clumsy wordplay changes the People's Republic of China into a "Confucian Socialist Republic," then goes on to assert that "the most profound significance of China's reforms is to unearth the profound implications of 'Confucian socialism,"' which it claims will be the "greatest task of China in the twenty-first century." (49) This thesis is as untenable as the other pronouncements the New Left has come up with (for example, attributing China's problems to the problems of globalised capitalism, holding that China's corruption and injustice arise from globalisation and multinational companies). At China's present stage, in which we continue to say that "democracy is a good thing," if the aforementioned bizarre notions of Confucian fundamentalists can gain traction, and the alliance of the New Left with Confucianists can be applauded, all that indicates is that China's intellectual enlightenment remains inadequate, that China's social realities are not yet sufficiently recognised, and that more effort needs to be devoted to this aspect.

\section{Iranslated by Stacy Mosher}

46. TN: Aka Huang Tsun-hsien (1848-1905), a writer and diplomat.

47. Quoted from Zhu Weizheng, "Guoxue Dawen," op. cit., p. 9.

48. TN: The Neo-Confucian Mou Zongsan was also influenced by Kant and Buddhism.

49. Gan Yang, "Zhongguo daolu: Sanshi nian yu liushi nian" (China's road: 30 years and 60 years), 26 June 2007, http://www. 360doc.com/content/07/0702/00/24133_589534.shtml. 